Editorial

\title{
New Traits of Agriculture/Food Quality Interface
}

\author{
Alessandra Durazzo (D) \\ CREA-Research Centre for Food and Nutrition, Via Ardeatina 546, 00178 Rome, Italy; \\ alessandra.durazzo@crea.gov.it
}

check for updates

Citation: Durazzo, A. New Traits of Agriculture/Food Quality Interface. Agriculture 2021, 11, 1182. https:// doi.org/10.3390/agriculture11121182

Received: 20 October 2021

Accepted: 10 November 2021

Published: 23 November 2021

Publisher's Note: MDPI stays neutral with regard to jurisdictional claims in published maps and institutional affiliations.

Copyright: (C) 2021 by the author. Licensee MDPI, Basel, Switzerland. This article is an open access article distributed under the terms and conditions of the Creative Commons Attribution (CC BY) license (https:/ / creativecommons.org/licenses/by/ $4.0 /)$.

\section{Introduction}

There is a close link between food and territory. The current challenges can be found in precision agriculture and food metrology from the perspective of monitoring and improving food quality and addressing the promotion of diversity of agroecosystems and diets. The study of Durazzo et al. [1] describes the metrology, agriculture, and food relationship by quantitative literature research analysis as a useful tool for identifying emerging research directions, collaboration networks, and suggestions for more in-depth literature searches.

Research studies describing factors affecting food quality-such as agronomic conditions, post-harvest elicitors, cultivar selection, harvest date, or environmental influences-are described. Sustainable environmental and innovative practices should be promoted.

$\mathrm{Hu}$ et al. [2] have compared the grain quality and starch physicochemical properties between Japonica rice cultivars with different contents of amylose, as affected by nitrogen fertilization: the selection of a low amylose content japonica rice cultivar grown without nitrogen fertilizer can reduce the amylose and protein contents, as well as improving the pasting properties, starch retrogradation properties and eating quality of the cooked rice.

Feledyn-Szewczyk et al. [3], by studying the milling and baking quality of spring wheat (Triticum aestivum L.) from organic farming, concluded on the basis of the 3-year study results that the most useful variety for organic production is Arabella, followed by Brawura, Izera, Kandela, Katoda, KWS Torridon, Waluta, and Zadra.

Boussahel et al. [4] described phenolic compounds and antioxidant properties of monocultivar olive oils from Northeast Algeria.

Ma et al. [5] showed how reasonable nitrogen fertilizer management improves rice yield and quality under a rapeseed/wheat-rice rotation system.

Jahangirlou et al. [6] showed a case study from the semiarid conditions of Iran on the study of grain quality of maize cultivars as a function of planting dates, irrigation, and nitrogen stress.

Botella et al. [7] studied bioactive compounds of tomato fruit in response to salinity, heat, and their combination: the results show the viability of exploiting abiotic stresses and their combination to obtain tomatoes with increased levels of health-promoting compounds.

Advanced techniques, such as mass spectrometry, infrared, and Raman spectroscopy, in the monitoring and control of foodstuffs for modeling the agrofood system should be considered. Innovative green technologies should be taken into account. Targeting food approaches should be promoted. Chemometrics applications are welcome.

For instance, Kędzierska-Matysek et al. [8] proposed a chemometric approach for studying the relationships linking the color and elemental concentrations of blossom honeys with their antioxidant activity.

Guilherme et al. [9] showed a comparative study on phenolics and antioxidant activity of green and red sweet peppers from organic and conventional agriculture: the results confirmed that the production system, as well as the maturation stage affect phenolic content and antioxidant activity, allowing their possible use as maturation-production biomarkers. Moreover, the authors mark how the chemometric approach reveals how 
phenolic composition together with the antioxidant capacities could be used to differentiate the production system and the maturation stage of sweet peppers.

Da Silva et al. [10] studied the effects of camu-camu (Myrciaria dubia) powder on the physicochemical and kinetic parameters of deteriorating microorganisms and Salmonella enterica subsp. enterica Serovar Typhimurium in refrigerated vacuum-packed ground beef: camu-camu powder addition decreases the lipid oxidation of vacuum-packed ground beef, although it influences color features leading to a decreased red hue in the camucamu powder-containing meat. Regarding antimicrobial activity, camu-camu powder does not interfere in S. enterica ser. Typhimurium behavior and does not extend the shelf-life of vacuum-packed ground beef based on the concentration of certain spoilage microorganisms, acting only on the kinetic bacterial behavior parameters [10].

Souza et al. [11] showed the physicochemical properties and antioxidant activity of spouted bed dried Rosmarinus officinalis extract.

The perspective of Durazzo et al. [12] is focused on antioxidant properties of bee products derived from medicinal plants as beekeeping sources.

It is worth mentioning that the preliminary study of Das et al. [13] evidenced how microbiome analysis of the rhizosphere from wilt-infected pomegranate reveals complex adaptations in Fusarium by demonstrating the capabilities of the whole metagenome sequencing approach for rapid identification of potential key players of wilt disease pathogenesis wherein the symptomatology is complex.

The papers included in this Special Issue cover a broad range of interdisciplinary aspects from agriculture and biology, chemistry, and nutrition. It is hoped that this Special Issue will stimulate further research in these areas.

Funding: This research received no external funding.

Conflicts of Interest: The authors declare no conflict of interest.

\section{References}

1. Durazzo, A.; Souto, E.B.; Lombardi-Boccia, G.; Santini, A.; Lucarini, M. Metrology, Agriculture and Food: Literature Quantitative Analysis. Agriculture 2021, 11, 889. [CrossRef]

2. Hu, Y.; Cong, S.; Zhang, H. Comparison of the Grain Quality and Starch Physicochemical Properties between Japonica Rice Cultivars with Different Contents of Amylose, as Affected by Nitrogen Fertilization. Agriculture 2021, 11, 616. [CrossRef]

3. Feledyn-Szewczyk, B.; Cacak-Pietrzak, G.; Lenc, L.; Gromadzka, K.; Dziki, D. Milling and Baking Quality of Spring Wheat (Triticum aestivum L.) from Organic Farming. Agriculture 2021, 11, 765. [CrossRef]

4. Boussahel, S.; Di Stefano, V.; Muscarà, C.; Cristani, M.; Melilli, M. Phenolic Compounds Characterization and Antioxidant Properties of Monocultivar Olive Oils from Northeast Algeria. Agriculture 2020, 10, 494. [CrossRef]

5. Ma, P.; Lan, Y.; Lv, X.; Fan, P.; Yang, Z.; Sun, Y.; Zhang, R.; Ma, J. Reasonable Nitrogen Fertilizer Management Improves Rice Yield and Quality under a Rapeseed/Wheat-Rice Rotation System. Agriculture 2021, 11, 490. [CrossRef]

6. Jahangirlou, M.; Akbari, G.; Alahdadi, I.; Soufizadeh, S.; Parsons, D. Grain Quality of Maize Cultivars as a Function of Planting Dates, Irrigation and Nitrogen Stress: A Case Study from Semiarid Conditions of Iran. Agriculture 2020, 11, 11. [CrossRef]

7. Botella, M.; Hernández, V.; Mestre, T.; Hellín, P.; García-Legaz, M.; Rivero, R.; Martínez, V.; Fenoll, J.; Flores, P. Bioactive Compounds of Tomato Fruit in Response to Salinity, Heat and Their Combination. Agriculture 2021, 11, 534. [CrossRef]

8. Kędzierska-Matysek, M.; Teter, A.; Stryjecka, M.; Skałecki, P.; Domaradzki, P.; Rudaś, M.; Florek, M. Relationships Linking the Colour and Elemental Concentrations of Blossom Honeys with Their Antioxidant Activity: A Chemometric Approach. Agriculture 2021, 11, 702. [CrossRef]

9. Guilherme, R.; Aires, A.; Rodrigues, N.; Peres, A.; Pereira, J. Phenolics and Antioxidant Activity of Green and Red Sweet Peppers from Organic and Conventional Agriculture: A Comparative Study. Agriculture 2020, 10, 652. [CrossRef]

10. Da Silva, J.L.; Cadavez, V.; Lorenzo, J.M.; Figueiredo, E.E.d.S.; Gonzales-Barron, U. Effects of Camu-Camu (Myrciaria dubia) Powder on the Physicochemical and Kinetic Parameters of Deteriorating Microorganisms and Salmonella enter-ica Subsp. enterica Serovar Typhimurium in Refrigerated Vacuum-Packed Ground Beef. Agriculture 2021, 11, 252. [CrossRef]

11. Souza, C.R.F; Baldim, I.; Bankole, V.O.; Da Ana, R.; Durazzo, A.; Lucarini, M.; Cicero, N.; Santini, A.; Souto, E.B.; Oliveira, W.P. Spouted Bed Dried Rosmarinus officinalis Extract: A Novel Approach for Physicochemical Properties and Antioxidant Activity. Agriculture 2020, 10, 349. [CrossRef] 
12. Durazzo, A.; Lucarini, M.; Plutino, M.; Pignatti, G.; Karabagias, I.K.; Martinelli, E.; Souto, E.B.; Santini, A.; Lucini, L. Antioxidant Properties of Bee Products Derived from Medicinal Plants as Beekeeping Sources. Agriculture 2021, 11, 1136. [CrossRef]

13. Das, A.J.; Ravinath, R.; Usha, T.; Rohith, B.S.; Ekambaram, H.; Prasannakumar, M.K.; Ramesh, N.; Middha, S.K. Microbiome Analysis of the Rhizosphere from Wilt Infected Pomegranate Reveals Complex Adaptations in Fusarium-A Preliminary Study. Agriculture 2021, 11, 831. [CrossRef] 